\title{
Population and Habitat Use of the Critically Endangered Grey-Backed Myna (Acridotheres tricolor) in the One of Easternmost Protected Area in Java
}

\author{
Bhisma Gusti Anugra ${ }^{1 *}$, Nurul L. Winarni ${ }^{1,2}$, Dimas Haryo Pradana ${ }^{1}$, Tom \\ Squires $^{3}$ \\ ${ }^{1}$ Dept. of Biology, Faculty of Mathematics and Science (FMIPA), Universitas Indonesia, Indonesia \\ ${ }^{2}$ Research Center for Climate Change Universitas Indonesia (RCCC-UI), Indonesia \\ ${ }^{3}$ Conservation, Evolution and Behaviour Research Group, Manchester Metropolitan University (MMU), United \\ Kingdom \\ ${ }^{*}$ Corresponding author. Email: bhisma.gusti@ui.ac.id
}

\begin{abstract}
Grey-backed myna (Acridotheres tricolor) is a critically endangered endemic bird of East Java with populations in nature fewer than 250 individuals. Baluran National Park is one of the last natural habitats of Grey-backed myna. This study aims to determine the relative abundance and habitat use of Grey-backed myna populations in several habitats in Baluran National Park. The relative abundance of bird populations was calculated using the encounter rates formula, while habitat use was analyzed using PCA. The study was conducted from October to November 2018 in savanna, forest-savanna, restoration-savanna, monsoon forest, acacia forest, and coastal forest. The results showed that the savanna habitat had the highest encounter rates of 11.16 , while the beach forest habitat is the habitat with the lowest encounter rates of 0. PCA analysis shows the habitat use of Greybacked myna tends to be determined based on the presence of Brachiaria reptans, Acacia nilotica, Corypha utan, dead tree trunks, and abundant trees with large diameter, also the few of Tamarindus indica and leaf litter. An understanding of the relative abundance and habitat use is important for the grey-backed myna conservation.
\end{abstract}

Keywords: Acridotheres tricolor, Habitat, Habitat Use, Relative Abundance

\section{INTRODUCTION}

The grey-backed myna (Acridotheres tricolor) is a medium-sized bird $(23 \mathrm{~cm})$ from the Sturnidae. These endemic birds of East Java can only be found in Baluran National Park, Alas Purwo National Park, and possibly in Meru Betiri National Park [1-3]. The grey-backed myna lives in a variety of terrestrial habitats, from closed habitats such as monsoons forest to open habitats such as savanna [4]. Generally, the population of grey-backed myna chooses savanna to find food such as fruit, nectar, and insects [5], [3]. When foraging for food, these birds form a small group of 2 to 3 individuals [6].
Based on the regulation of the Minister of Environment and Forestry of the Republic of Indonesia number P.106/MENLHK/SETJEN/KUM.1/12/2018, grey-backed myna (Acridotheres tricolor) is one of the songbird species that is registered as a protected animal [7]. Even though they are protected, this bird is often hunted and becomes the target of the illegal wildlife trade [8]. Apart from being a result of poaching, the population of grey-backed myna also faces threats due to habitat loss and the presence of pesticides [8], [9]. These threats cause the population of grey-backed myna in nature continue to decline, thus make this bird 
critically endangered [2]. It is estimated that currently, the population of this species is fewer than 250 individuals in the wild [10].

Although the population of grey-backed myna is threatened and continue to decline, the research about grey-backed myna in their natural habitat is still rare. Several studies regarding the population studies of grey-backed myna in their natural habitat have been conducted by [5], [11], [12], but have not been published. The lack of information about grey-backed myna in their natural habitat is the reason why this research was conducted. The purpose of this study was to determine and analyze the relative abundance and habitat use of the grey-backed myna population based on environmental variables in various habitats in the Baluran National Park area. Understanding the abundance and habitat use is important for the conservation of the grey-backed myna population because by doing these studies we can find out the need of grey-backed myna population in their habitat. The results of this study are expected to be used as basic information for the conservation management of the grey-backed myna, especially in Baluran National Park.

\section{MATERIALS AND METHODS}

\subsection{Location and Time of Research}

This research was conducted in Baluran National Park, East Java, Indonesia. The pre-research field survey was carried out on the 11th-15th May 2018, this field survey aims to understand the condition of the study area. Data were collected from October 2018 to mid-November 2018 in the dry season. The research was carried out in a study area of $14,8 \mathrm{~km}^{2}$ that occupies the Kramat and Bama Resort. Six habitats were used as the observation area, namely grassland savanna, woodland savanna, monsoon forest, acacia woodland, and beach forest. The map of the observation area can be seen in Fig 1.

\subsection{Tools and Materials}

The tools used in this research are stationary, notebook, wood stick with a length of $1 \mathrm{~m}$ long, compass, laser rangefinder [Hawke LRF-600], DBH meter [Forestry Suppliers Inc.], prosumer camera [Nikon Coolpix B700], DSLR camera [Canon Eos 700D] with 18-200 mm lens [Tamron], binocular [Vortex Diamondback], GPS [Garmin GPSmap 62], tripod, bird identification book by [6], and guidebook of birds in Baluran by [13]. The Object of this research is grey-backed myna (Acridotheres tricolor, Horsfield 1821).

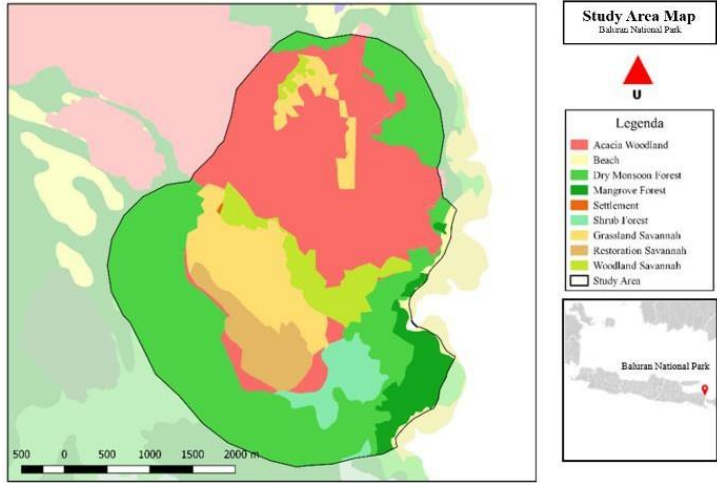

Figure 1. Map of the study area in Baluran National Park

\subsection{Bird Population Data Sampling}

Bird Population data were collected using visual encounter survey method in the study area. When observers find the grey-backed myna, the point where the observer encounter the bird serves as an observation point. Things that are noted when observer find grey-backed myna are the time when the bird appeared, GPS coordinates, number of individuals, the distance between the observer and the bird, the axis between the observer and the object, bird behavior, tree height (if the bird was perched), the place where the bird perched (whether if it's on the tree or ungulates), and other information. The bird observation is done both visually and audio.

There are four periods for observation time, 05:20 AM-08:30 AM (period 1), 08:30 AM-11:30 AM (AM (period 2), 11:30 AM-14:30 PM (period 3), and 14:30 PM17:30 PM (period 4). In one day, observations were made at two different periods. The chosen timing was based on the optimal time for the bird to do their daily activities such as foraging for food and singing [14]. Also, the observation was divided into four periods aimed at determining the relative abundance of grey-backed myna at each time. Bird identification was carried out using bird identification books.

\subsection{Habitat Structures and Data Sampling}

Habitat structure data was collected using the point quarter method with an area of $20 \mathrm{~m}$ in diameter (Fig 2.). The habitat structure data that was recorded were habitat type, understory layer, percentage of ground cover, tree data, list of plant species at the observation point, and some features on the observation point. In addition, the observation point was also photographed to get an overview of the habitat. 
There are two habitat structure data collection. The first one is the habitat structure data recorded at the point when the observer saw grey-backed myna. The second habitat structure data is the habitat structure data that were recorded on the random habitat point. These random habitat points were determined using QGIS v.2.18.16 randomly. In total, there are 131 random habitat points scattered throughout the study area.

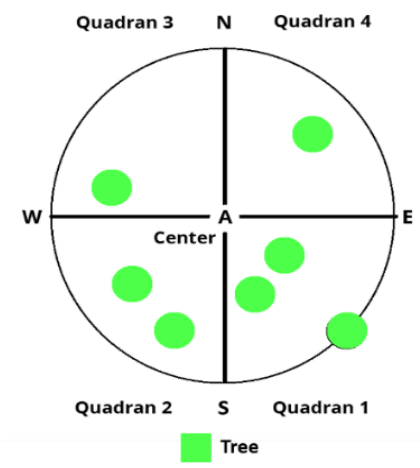

Figure 2. Point quarter method diagram (source: [15] with adjustment)

\subsection{Understory Layer Data Collection}

The understory layer percentage was calculated using a stick with a length of $1 \mathrm{~m}$. The stick was placed on the shoulder horizontally, then the observer rotates $360^{\circ}$ swinging the stick and count how many plants that hit by the stick. The plants that were hit by the stick were counted to represent the percentage of the understory layer [16].

\subsection{Ground Cover Data Collection}

The percentage of the ground cover was calculated by estimating the percentage of ground cover types that exist in the observation point, the total estimated percentage of the ground cover must be $100 \%$ [16]. The ground cover types recorded were bare ground, grass, herbs, rocks, water, leaf litter, and other ground covers that are not included in the previous 6 types.

\subsection{Tree Data Collection}

The tree data that recorded were highest tree species, the average diameter of the three highest trees in the observation point, the condition of fruiting and inflorescences, and the species name of the tallest tree in the observation point.

\subsection{Plants Species Data Collection}

The plant species data collection was recorded by filling in the list of plant species whether there are plant species in the observation point listed on the observation sheet or not. There are 16 types of plants listed on the observation sheet: pilang (Acacia leucophloea), A- nilotica, jati (Tectona grandis), Palm, gebang (Corypha utan), neem (Azadirachta indica), widoro bukol (Ziziphus rotundifilia), asam (Tamarindus indica), Lantana camara, Thespesia lampas, Calotropis gigantea, Mimosa invisa, Dicanthium caricosum, Themeda arguens, Brachiaria reptans, and Elusine indica. The selection of these species was based on information from the pre-research survey and the research conducted by [11] and [12].

\subsection{Plants Species Data Collection}

There are some additional features recorded to explain the presence of grey-backed myna in the observation area. These features were the presence of ungulate dung, the ungulate traces, man-made roads, the Acacia restoration, burn marks, the dead trunk that still standing and how many stems there are, evidence of planting activity, and water source. The selection of these features was based on the research conducted by [11] and [12].

\subsection{Relative Abundance of Grey-Backed Myna Population}

Table 1. The ordinal scale of abundance category

\begin{tabular}{lll}
\hline $\begin{array}{l}\text { Abundance category } \\
\text { Number of individuals } \\
\text { per 100 field hours }\end{array}$ & $\begin{array}{l}\text { Abundance } \\
\text { Score }\end{array}$ & $\begin{array}{l}\text { Ordinal } \\
\text { Scale }\end{array}$ \\
\hline$<0,1$ & 1 & Rare \\
$0,1-2,0$ & 2 & Uncommon \\
$2,1-10,0$ & 3 & Frequent \\
$10,1-40,0$ & 4 & Common \\
$40,0+$ & 5 & Abundant \\
\hline
\end{tabular}

(Source: [14])

The relative abundance of grey-backed myna population in each habitat was calculated using encounter rates formula:

$$
\begin{aligned}
& \text { Encounter rates (individual/hour) }= \\
& \frac{\text { The number of individuals grey-backed myna }}{\text { Number of observations hours }}
\end{aligned}
$$


Then the result of the calculation then matched with the ordinal scale of abundance category. The ordinal scale of abundance category can be seen in Table 1.

\subsection{Habitat Use Analysis}

Habitat use analysis was analyzed by using Principal Component Analysis (PCA). Using PCA, we are trying to find out whether the presence or absence of grey-backed myna is affected by all the variables in habitat structure data.

\section{RESULT AND DISCUSSION}

\subsection{The Relative Abundance of Grey-Backed Myna in Each Habitat}

In general, grey-backed myna was found almost in all habitats in the study area. Based on the calculation of encounter rates, it is found that grassland savanna is the habitat with highest encounter rates, with 11,16 . It can be said that the relative abundance of grey-backed myna population in grassland savanna is "common". Moonsoon forest is the highest enclosed habitat with the encounter rates of 5,3. It can be said that the relative abundance of grey-backed myna population in monsoon forest is "frequent". The habitat with the lowest encounter rates is the beach forest, with encounter rates of 0 . The detail comparation of encounter rates for each habitat are shown in Fig 3.

Savanna is one of the largest and most important ecosystems in Baluran National Park, with $40 \%$ of the Baluran National Park area is savanna. It is also served as an identity and distinctive characteristic for the national park itself [17-19]. Most of the animals use savanna as a place to do their activities, one of the animals that use savanna is grey-backed myna. Based on encounter rates, the grey-backed myna population was common in both grassland savanna and woodland savanna. It is because the savanna is the main habitat for grey-backed myna for foraging. The savanna grasses are the habitat for insects that serve as the potential food for grey-backed myna [5], [8]. Moreover, the savanna grasses are also served as the food for the ungulates, such as Timor deer (Rusa timorensis), and buffalo (Bubalus bubalis). Greybacked myna exploits the ungulates by eating insects or ectoparasites on the surface of those ungulates skin [13], [11]. Some of the tree species in woodland savanna such as pilang (Acacia leucophloea), neem (Azazdirachta indica), and widoro bukol (Ziziphus rotundifolia) used as a place to eat, perch, and rest [5], [11]. Those species also provide shade for animals from sunlight in the noon [18], [20], [21].

Besides savanna, the monsoon forest also serves as one of the important ecosystems in Baluran National Park. This ecosystem serves as a habitat for ungulates such as Timor deer (Rusa timorensis), and buffalo (Bubalus bubalis) [22]. Based on encounter rates, the grey-backed myna population was frequently found in monsoon forest. The population of grey-backed myna is often found in monsoon forest, especially during the dry season, because the resources are limited in savanna, so the bird population uses some plants in the monsoon forest to fulfill their daily needs [5]. Plant species such as neem (Azadirachta indica), tamarind (Tamarindus indica), and pilang (Acacia leucophloea) are common in Baluran monsoon forest. These species are used by grey-backed myna as a source of food, a place to rest, and a place to sleep [9], [11]. In addition, the

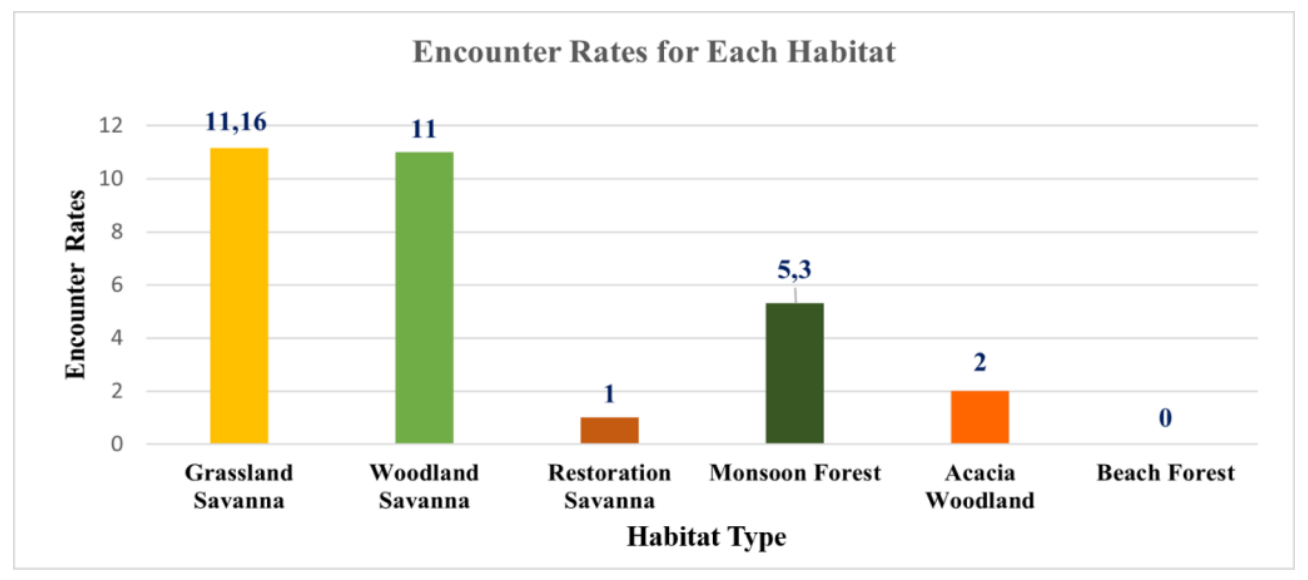

Figure 3. Grey-backed myna encounter rates chart for each habitat 
canopies of trees in the monsoon forest can be used as a shelter for grey-backed myna to avoid predators due to the thick leaves and tree branches covering them [23-24]. There is an interesting note that during the observation activity, the presence of grey-backed myna in the monsoon forest was recorded almost coinciding with the presence of groups of Timor deer in periods 2 and 3. It was suspected that the movement of grey-backed myna into the monsoon forest was also caused by following groups of ungulate animals that move to monsoon forest in search of shelter [5].

The Baluran National Park has major issue with the invasion of Acacia nilotica. This species is disturbing the balance of the ecosystem in Baluran, especially the savanna ecosystem. The invasion of A. nilotica has caused threat to various grass species in the savana ecosystem, thus resulting the decline of the Baluran savanna [18], [25]. Various attempts have been made to eradicate A. nilotica in Baluran, both chemically and mechanically [18]. The restoration savanna ecosystem was originally an acacia woodland ecosystem which invaded the savanna, but the forest was then cut down as an effort to eradicate the invasion of A. nilotica. Based on encounter rates, the grey- backed myna population were uncommon in restoration savanna with encounter rates of 1 , we assume that it has something to do with the dry season when this research was conducted. The dry season in Baluran National Park last from May to November. During the dry season, the production of green grass in the Baluran savanna will decrease, thus make the main resources in the savanna decline [18], [26].

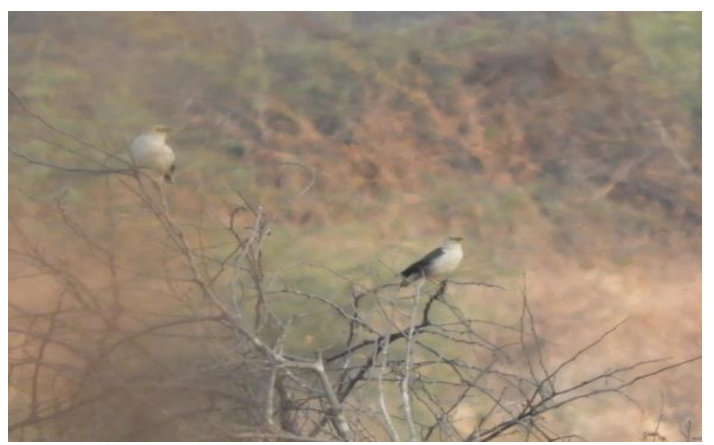

Figure 4. Grey-backed myna perch on the remains of Acacia nilotica tree that has been cut in the restoration savanna

Due to the scarcity of resources in the restoration savanna habitat, there were also few animals that use the restoration savanna habitat. However, based on research conducted by [11] and
[12], grey- backed myna were often found in restoration savanna in search of food during the rainy season as shown on Fig. 4. Even though the existence of acacia woodland is a serious problem in Baluran National Park, some animals still use acacia woodland. Based on the results of the calculation of encounter rates, the relative abundance of grey-backed myna in acacia woodland is "Uncommon". It was thought that acacia woodland has few resources that can be utilized by animals in Baluran National Park. Although acacia woodland has few resources, greybacked myna still uses the acacia as a place for rest, perching, sunbathing, and foraging [5], [27]. Similar to what happened in monsoons forest, it was noted that the presence of grey-backed myna in acacia woodland was recorded almost coinciding with the presence of groups of Timor deer taking shelter under the canopy of A. nilotica. The presence of deer in acacia woodland will be followed by a population of grey-backed myna because grey-backed myna will follow the movements of ungulate animals [5].

\subsection{Habitat Use of Grey-backed Myna Population}

The habitat use of grey-backed myna was analyzed using Principal Component Analysis (PCA). From all the variables in habitat structure data that used in this analysis, the principal component from PCA result that used for habitat use analysis were PC1 and PC2. Based on analysis with PCA, there are five variables on PC1 and four variables on PC2. The five variables on PC1 were leaf litter (- 0.747), tree dbh average (-0.439), Acacia nilotica (0.558), Tamarindus indica (0.675), and Brachiaria reptans (0.621). The four variables on PC2 were tree dbh average $(0.675)$, tree height (0.720), dead trunk (0.738), and gebang (Corypha utan) tree (0.809). The results of the scatter plot shows that there is an overlap between the presence and absence group of grey-backed myna population. The presence group tends to be clustered in PC1, while the absence group is more spread out although some are clustered on PC1 as shown in Fig. 5.

Based on the PCA result, we suggest that the population of grey-backed myna tends to use habitat structures with lots of Brachiaria reptans, Acacia nilotica, gebang (Corypha utan), trees with large diameters, dead tree trunks, and abundant trees with large diameter, also the habitat with few of Tamarindus indica and leaf litter. The variables in these conditions indicate the structure of a 
habitat that tends to be open habitat such as savanna or woodland savanna.

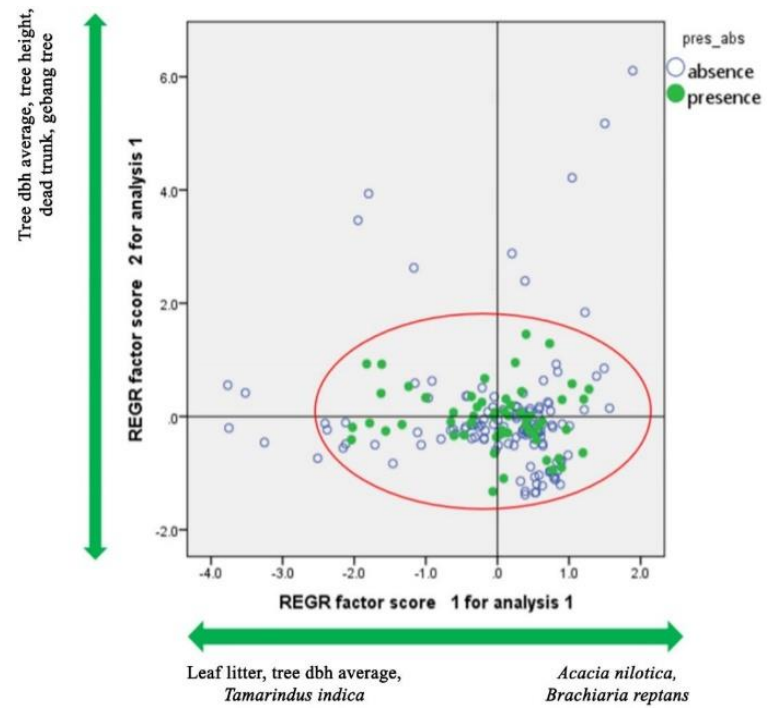

Figure 5. The scatter plot figure of presence and absence of grey-backed myna to PC1 and PC2

During the observations, most of the records encounters of grey-backed myna tend to be found in grassland and woodland savanna than other habitats as shown in Fig 6, with 24 and 27 encounters in grassland savanna and woodland savanna respectively (Fig 7). Savanna is an intermediate habitat between forest and grasslands. There are three general types of vegetation in savanna: trees, grass, and herbs, where some of these plant species have the ability to withstand fire [18], [28]. Based on the topography, the Bekol savanna is included as flat savanna [18]. The types of plants found in the savanna in Baluran National Park are dominated by grasses such as Brachiaria reptans and herbaceous species such as Thespesia lampas. There also some species of trees that grow on the savanna, including acacia (Acacia nilotica), pilang (Acacia leucophloea), neem (Azadirachta indica), widoro bukol (Ziziphus rotundifolia), and gebang (Corypha utan). A. leucopholea, $Z$. rotundifolia, and $C$. utan are trees that tend to have a large diameter, reaching more than $50 \mathrm{~cm}$. Brachiaria reptans is an important variable for grey-backed myna because this species of grass is food for ungulates, and these species are abundant in the savanna. The savanna also had many dead trunks during the dry season. These dead trunks contain some insects that serve as food for birds like grey-backed myna.

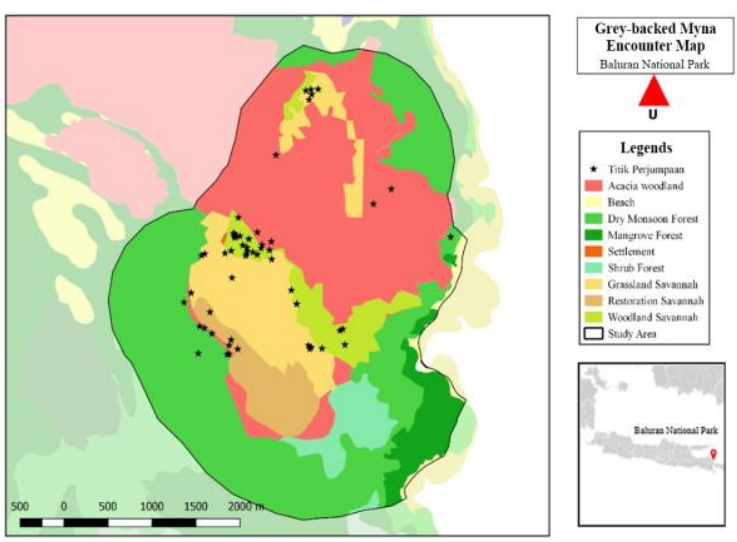

Figure 6. The grey-backed myna encounter map, the black dots shown the location where the bird found

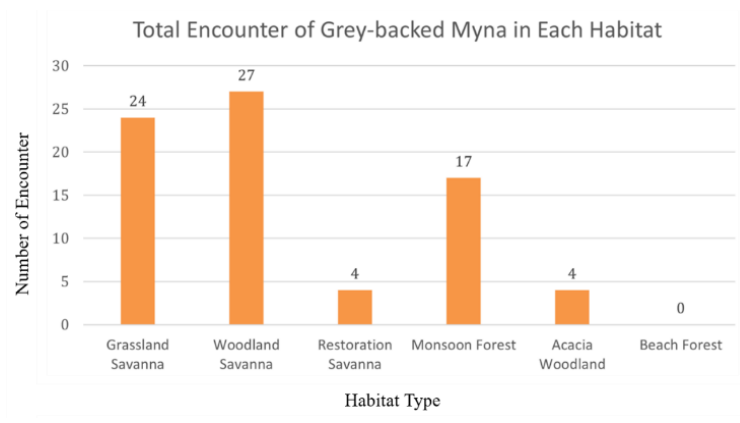

Figure 7. The chart of total encounter of greybacked myna in each habitat

Based on the PCA results, A. nilotica is one of the variables that affect the presence of grey-backed myna. This is fit with the observation because during the observation, several grey-backed mynas were recorded to be found perching on A. nilotica trees. According to [1], grey-backed myna use $A$. nilotica as a place to look for foods. Insects are one of the potential foods for grey-backed myna. usually, they eat Camponotus sp., Solenopsis sp., grasshopper, Valanga nigricornis, Phyllium fulchrifolium, and fleas [1], [5], [9]. It is suspected that A. nilotica affects the presence of grey-backed myna in a habitat because $A$. nilotica provides the insects that serve as food for grey-backed myna. In addition, during the observation, the grey-backed myna also used A. nilotica as a place to perch and do other activities such as singing and searching. $A$. nilotica is used by birds as a resting place and perching place for birds to eat fruit or flowers from other nearby trees [29]. During the observation, it was observed that in the dusk (period 4), a large group of grey-backed myna flew across the Bekol 
savanna towards the acacia woodland which is located north of the Bekol savanna. It is thought that A. nilotica is used by grey-backed myna as a place to sleep or rest. The spiny stem structure of $A$. nilotica is thought to make A. nilotica a safe sleeping place from predators. However, further observation is still needed to support this.

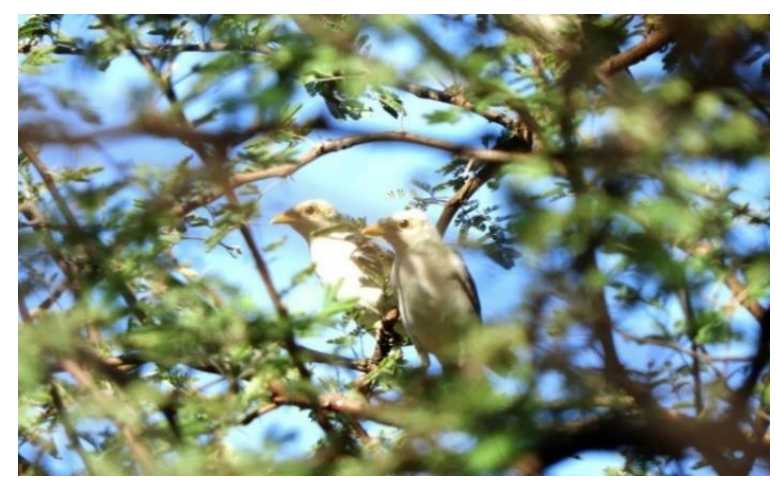

Figure 8. A Pair of grey-backed myna hiding in A. nilotica tree

Another plant species that serve as variables that affect the presence of grey-backed myna is gebang (Corypha utan). During the observation, grey-backed myna was recorded several times perched on gebang tree. According to [5] and [11], grey-backed myna uses gebang as a nesting tree. It is also confirmed by the national park ranger that grey-backed myna usually uses gebang tree as the nesting tree. Gebang (C. utan) can grow to more than $18 \mathrm{~m}$ and the diameter of more than $40 \mathrm{~cm}$, these characteristics make gebang tree serve as a safe nest tree for grey-backed myna [24], [30].

The PCA results show that although grey-backed myna prefers habitats with less tamarind (Tamarindus indica) trees, grey-backed myna is also using tamarind trees. In Baluran National Park tamarind trees can be found in monsoon forest, where this habitat also has a lot of leaf litter. Greybacked myna uses tamarind trees as a place to do their daily activities. The tamarind tree has a large canopy and many branches, making it a suitable place for grey-backed myna to sunbathe, rest, foraging, and a safe place to sleep [5], [11], [24].

There were several variables that were recorded to be utilized by grey-backed myna but did not appear as a variable in the PCA results. These variables include several plant species and ungulates were recorded as being visited and utilized by grey-backed myna. The plant species recorded to utilized by grey-backed myna are neem (Azadirachta indica), widoro bukol (Ziziphus rotundifolia), and pilang (Acacia leucophloea). The ungulates that recorded to be utilized by greybacked myna are Timor deer (Rusa timorensis) and Buffalo (Bubalus bubalis) (Table 2).

Table 2. The table of total plant and ungulates that recorded visited by grey-backed myna

\begin{tabular}{lll}
\hline Species & Species Name & $\begin{array}{l}\text { Total } \\
\text { Visited }\end{array}$ \\
\hline Akasia & Acacia nilotica & 10 \\
Pilang & Acacia leucophloea & 10 \\
Neem & Azadirachta indica & 10 \\
Widoro & Ziziphus & 4 \\
Bukol & rotundofilia & \\
Rusa Timor & Rusa timorensis & 6 \\
Kerbau & Bubalus bubalis & 2
\end{tabular}

Pilang (Acacia leucophloea) is one of the Acacia's species that can be found in Baluran National Park beside the invasive A. nilotica. This species usually grows in the semi-arid area below $900 \mathrm{~m}$ asl that have dry season of 9-10 months [3132]. In Baluran A. leucophloea serves as important species in savanna along with other plant species such as neem, gebang, and widoro bukol [33]. Based on observation, grey-backed myna uses pilang as a place to perch, sing, and rest, especially in the afternoon. This is in accordance with the study conducted by [5], [11], and [12]. According to them, usually grey-backed myna uses pilang as a place to do their daily activities such as singing, rest, and nesting. Also, the information from Baluran National Park ranger also supports that pilang was used by grey-backed myna as its nesting site. The structure of pilang tree that have many branches makes the tree a safe place to rest and to make a nest for grey-backed myna [5].

Neem (Azadirachta indica) is a species of plant that is quite common in the Baluran, especially in the savanna [5], [33]. During the observation, many neem trees were and flowering. Ripe neem fruit has a yellow-green or yellowish color [34]. The behavior of grey-backed myna eating neem food was recorded during the observation. According to [4], grey-backed myna will perch on low tree branches and come down to the ground to eat fruit that has fallen. This is in accordance with the observation that when grey-backed myna ate neem fruit, they perch on the lower branches of the neem tree then came down to the ground to eat the fallen neem fruit. After that, they will fly to the lower branches of the neem tree and came back down to the ground again to eat. This is done repeatedly. In 
addition, grey-backed myna uses neem as a place for rest, perch, and sunbathing [5].

Another plant species that was used by greybacked myna is widoro bukol (Ziziphus rotundifolia). Widoro bukol is one of the common species in savana [11], [18]. During the observation, grey- backed myna was seen several times visiting the widoro bukol tree to perch, singing, and preening. Usually, grey-backed myna uses widoro bukol tree as a place to do their daily activities. According to [5], grey-backed myna also eats the fruit from widoro bukol tree. However, this activity was not recorded during the observation. Possibly it's because during the observation Baluran experiencing the dry season, while widoro bukol bears fruit during the rainy season [35].
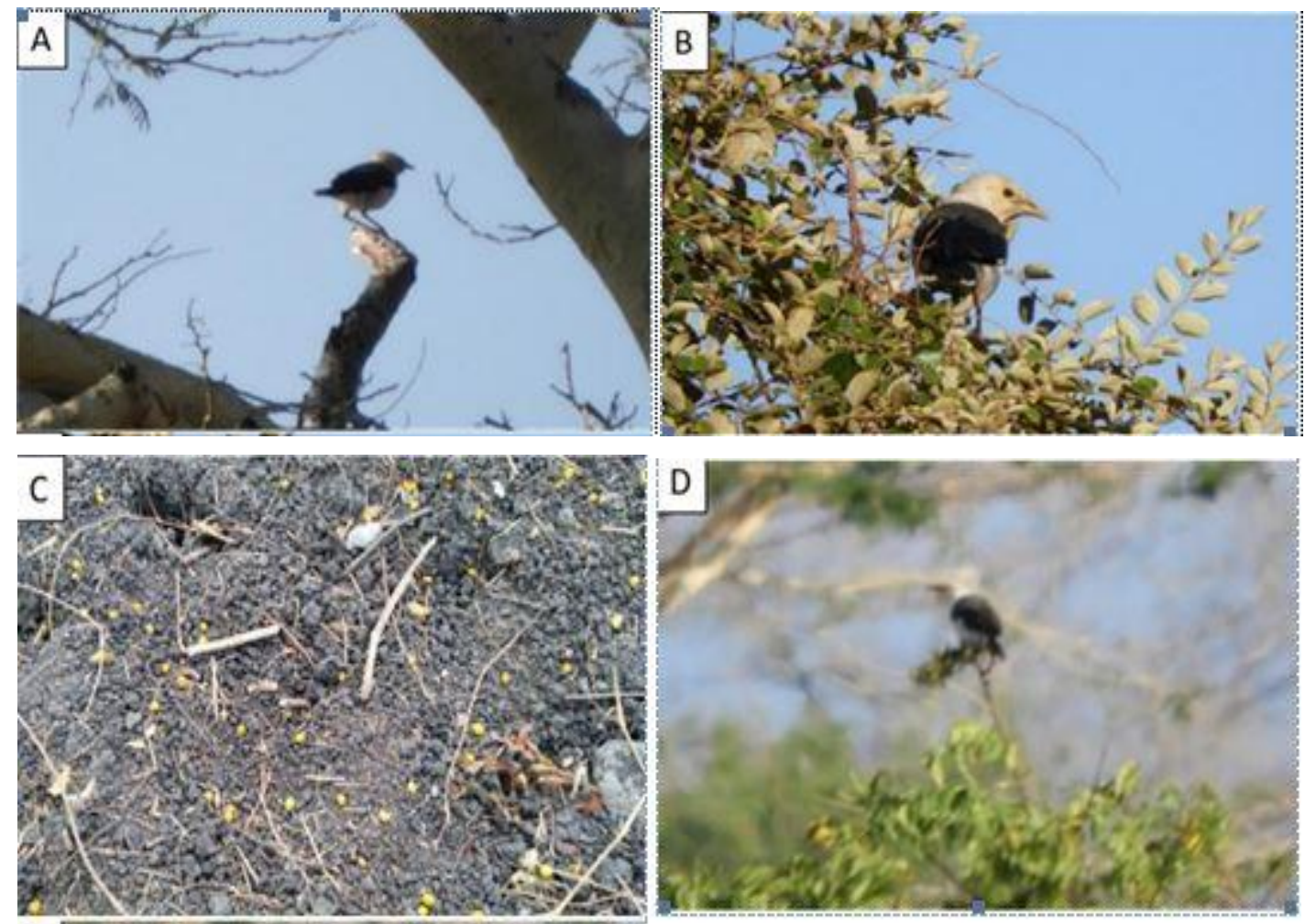

Figure 9. A. Grey-backed myna perch at Acacia leucophloea; B. Grey-backed myna perch at Ziziphus rotundifolia; C. The fallen ripe fruit of Azadirachta indica; D. Grey-backed myna sunbathing at Azadirachta indica

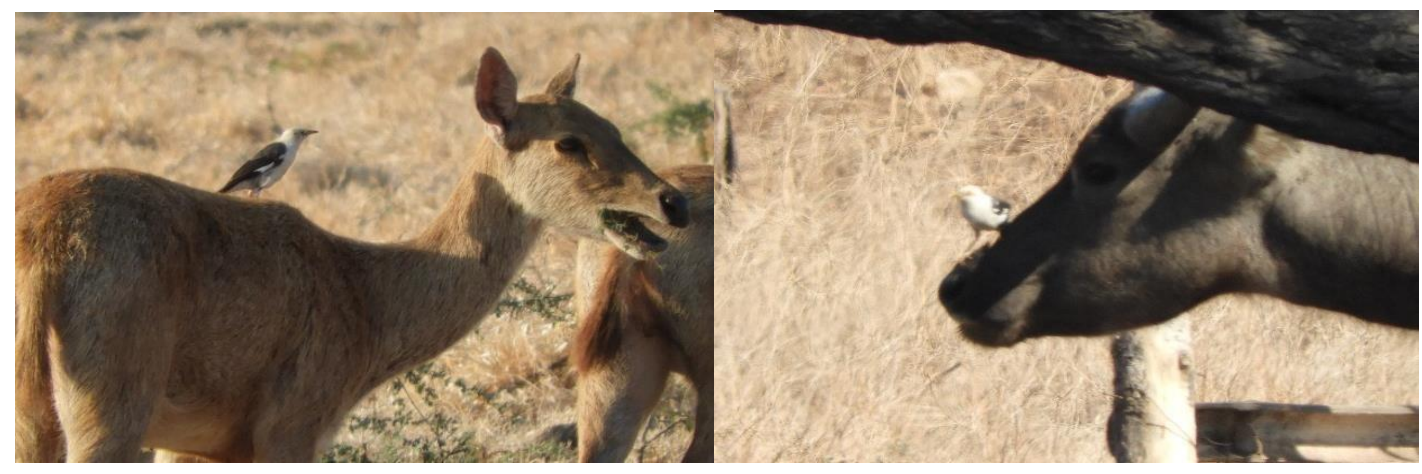

Figure 10. Grey-backed myna perch at the back of the Timor deer (Rusa timorensis) (left); Grey-backed myna perch at snout of buffalo (Bubalus bubalis) (right) 
Grey-backed myna was frequently encountered along with ungulate animals such as Timor deer (Rusa timorensis) and buffalo (Bubalus bubalis) as shown on Fig 10. These two ungulates' species are common in Baluran National Park. During the observation, grey-backed myna was recorded foraging on the back of the ungulates, their noses, and their ears. Most of the records about the behavior of the grey-backed myna perch on the back of the ungulates stated that grey-backed myna perch on the back of the ungulates for foraging [4-5], [11-13]. There is some mutualism between grey-backed myna and the ungulates. According to [36], the body part of ungulates that are most frequently targeted by birds are the parts on the head and its back, noses, and ears to find insects and parasites that served as their food. In addition, when these ungulates grazing, they will disturb the insects that are on the grass so they will hop or fly. This makes grey-backed myna easier to catch their food [5], [9].

During the observation, the grey-backed mynas were more often seen with Timor deers than buffaloes. The encounters of grey-backed mynas and Timor deer were almost found in every observation period (period I-IV). In addition, there is some assumption that grey-backed and the Timor deer have mutualism. The assumption is the grey-backed myna and Timor deer use each other as a warning sign against threats. The assumption arises because during the observation, especially in closed habitats such as monsoon forest and acacia woodland, the greybacked myna almost always coincides with the group of the Timor deer. Another argument is sometimes when the observer meets the group of Timor deer resting or graze in the monsoon forest and acacia woodland accidentally, the group will think human as a threat, and they will make a warning sign "scream". When the deers "scream" their warning sign, the observer just found out that there were also a group of grey-backed mynas in the trees around the deers. However, further observation is still needed to support the assumption about the warning sign between grey-backed myna and Timor deer.

\section{CONCLUSION}

The savanna serves as an important habitat for grey-backed myna. The grey-backed myna were common in grassland savanna with encounter rates score 11.16 , thus grey-backed myna is common in grassland savanna. The presence of Grey-backed myna tends to be determined based on the presence of Brachiaria reptans, Acacia nilotica, gebang (Corypha utan), dead tree trunks, and abundant trees with large diameter, also the few of Tamarindus indica and leaf litter on its habitat. In addition, the grey-backed myna also uses some plant species such as A. leucophloea, Azadirachta indica, and Ziziphus rotundifolia, also the ungulates. There are still very little researches about this myna in their natural habitat. The lack of research on this endemic bird does not mean there is no hope to save this critically endangered endemic species from extinction. We can learn from other myna like the Bali myna case, about how the conservation efforts have succeeded in increasing population of a critically endangered species in nature.

\section{ACKNOWLEDGMENTS}

This research is part of the "Survival Ecology for the Mynas and Other Songbirds Imperilled by the Cagebird Trade Crisis Across Java and Bali, Indonesia" research project who was implemented by Tom Squires. The research would not have been successful without the assistance from supervisors, the author's parents, and co-authors especially from the Department of Biology, Faculty of Mathematics and Natural Sciences, Universitas Indonesia and Manchester Metropolitan University.

\section{REFERENCES}

[1] F.A. Hosiana, Manajemen dan Faktor Penentu Keberhasilan Pelepasliaran Jalak Putih di Kawasan Hutan Pongkor, Bogor, Unpublished manuscript, Undergraduate thesis Faculty of Forestry, IPB University, Bogor, Indonesia, 2013. [In Bahasa Indonesia]

[2] Birdlife International, Acridotheres tricolor, The IUCN Red List of Threatened Species [Internet], 2018, e.T103870973A134212688. Available from https://dx.doi.org/10.2305/IUCN.UK.20182.RLTS.T103870973A134212688.en.

[3] Handbook of the Birds of the World Alive, Grey-backed Myna (Acridotheres tricolor), The Cornell Lab of Ornithology, Birds of the World [Internet], 2018. Available from: http://www.hbw.com/ species/grey- backedmyna-acridotheres-tricolor.

[4] M. Strange, A Photographic Guide to the Birds of Indonesia Second Edition, Tuttle Publishing Singapore, 2012.

[5] P.P. Widyaningrum, Populasi, Habitat, dan Perilaku Jalak Putih (Sturnus melanopterus Daudin, 1800) di Savana Bekol Taman Nasional Baluran, Unpublished manuscript, 
Undergraduate thesis, Faculty of Forestry, IPB University, Bogor, Indonesia, 2015, viii+33 pages. [In Bahasa Indonesia]

[6] J. MacKinnon, B.V. Balen, K. Phillipps, Seri Panduan Lapangan Burung- Burung di Sumatera, Jawa, Bali, dan Kalimantan, Puslitbang Biologi LIPI, Bogor, 2010, xvii+510 pages. [In Bahasa Indonesia]

[7] Minister of Environment and Forestry Republic of Indonesia, Peraturan Menteri Lingkungan Hidup Dan Kehutanan Republik Indonesia Nomor P.106/ Menlhk/Setjen/Kum.1/12/2018 Tentang Perubahan Kedua Atas Peraturan Menteri Lingkungan Hidup dan Kehutanan Nomor P.20/MENLHK/SETJEN/KUM.1/6/ 2018 Tentang Jenis Tumbuhan dan Satwa Dilindungi, Kementerian Lingkungan Hidup dan Kehutanan Republik Indonesia, Jakarta, 2018.

[8] N.J. Collar, A.V. Andreev, S. Chan, M.J. Crosby, S. Subramanya, J.A. Tobias, Threatened Birds of Asia: The Birdlife International Red Data Book. Birdlife International, Cambridge, 2001.

[9] D.H. Brillianti, J.B. Hernowo, L.B. Prasetyo, Populasi dan Habitat Jalak Putih (Sturnus melanopterus Daudin 1800) di Taman Nasional Bali Barat, Jurnal Pengelolaan Sumberdaya Alam dan Lingkungan 9(1) (2019) 97-105. DOI: 10.29244/jps1.9.1.97-106. [In Bahasa Indonesia]

[10] Birdlife International, Species Factsheet: Acridotheres tricolor, Birdlife International [Internet], 2020. Available from: http://datazone.birdlife.org/ species/factsheet/grey-backed-mynaacridotheres-tricolor.

[11] Y. Wulandari, Pembagian Relung Ekologis Pada Jalak Putih (Acridotheres melanopterus tricolor) dengan Jenis Burung Lainnya di Taman Nasional Baluran, Jawa Timur, Undergraduate thesis, Faculty of Mathematics and Natural Sciences, Universitas Indonesia, Depok, Indonesia, 2018, xii+48 pages. [In Bahasa Indonesia]

[12] D.S. Sanjaya, Perilaku Harian Jalak Putih (Acridotheres Melanopterus Tricolor) Berdasarkan Struktur Habitat di Taman Nasional Baluran, Jawa Timur, Undergraduate thesis, Faculty of Mathematics and Natural Sciences, Universitas Indonesia, Depok, Indonesia, 2018.
[13] S. Winnasis, Sutadi, A. Toha, R. Noske, Birds of baluran national park, Balai Taman Nasional Baluran, Situbondo, 2011.

[14] C. Bibby, M. Jones, S. Maarsden, Expedition Field Techniques: Bird surveys, Royal Geographical Society, London, 1998.

[15] Ecology and Evolution, Sampling Trees Using the Point Quarter Method, EcologyandEvolution.org [Internet], 2014. Available from: http://www.ecologyandevolution.org/documents /quartermethoddetails.pdf.

[16] S. Valle, Population Viability and Conservation of Grey Parrots on the Island of Principe, Gulf of Guinea, Doctoral Dissertation, Manchester Metropolitan University, 2015, xiii+197 pages.

[17] Hernowo, Kajian Terhadap Habitat dan Penyebrangan Lokal Merak Hijau (Pavo muticus Linneaus 1758) di Taman Nasional Baluran, Jawa Timur, Media Konservasi 6(1) (1999) 1522.

DOI: https://doi.org/10.29244/medkon.9.2.69-76. [In Bahasa Indonesia]

[18] M.Y. Sabarno, Savana Taman Nasional Baluran, Biodiversitas 3(1) (2002) 207-212. DOI: https://doi.org/10.13057/biodiv/d030107. [In Bahasa Indonesia]

[19] Baluran National Park, Profil Taman Nasional Baluran, Taman Nasional Baluran [Internet], 2018. Available from: http://baluran nationalpark.web.id/ profil-taman- nasionalbaluran. [In Bahasa Indonesia]

[20] Djufri, Pengaruh Tegakkan Akasia (Acacia nilotica) (L.) willd. ex. del. Terhadap Komposisi dan Keanekaragaman Tumbuhan Bawah di Savana Balanan Taman Nasional Baluran Jawa Timur, Jurnal Matematika, Sains dan Teknologi 5(2) (2004) 107-124. [In Bahasa Indonesia]

[21] B.R. Masy’ud, Wijaya, L.B. Santoso, Pola Distribusi, Populasi dan Aktivitas Harian Rusa Timor (Rusa timorensis, de Blainville 1822) di Taman Nasional Bali Barat, Media Konservasi 12(3) (2007) 10-15. DOI: https://doi.org/10.29244/medkon.12.3.\%25p [In Bahasa Indonesia]

[22] Taman Nasional Baluran, Laporan Kegiatan Pengendali Ekosistem Hutan: Pengumpulan Data dan Informasi Produktifitas Savana Bekol 
pada Musim Kemarau, 2006. [In Bahasa Indonesia]

[23] S.T. Pang, A.F. Sapian, K. Ismail, A.A. Tuen, Above-Ground Space Utilization and Feeding Guild of Tropical Rainforest Bird in Sarawak, Borneo, Transaction on Science and Technology, 4(4) (2017) 504-512.

[24] D.H. Brillianti, Kesesuaian Habitat dan Perkembangan Populasi Jalak Putih (Sturnus melanopterus Daudin 1800) di Taman Nasional Bali Barat, Postgraduate thesis, IPB Graduate Schhool, IPB University, Bogor, Indonesia, 2018, ii+62 pages. [In Bahasa Indonesia]

[25] Djufri, Analisis Vegetasi pada Tegakan yang Terinvasi Akasia (Acacia nilotica) di Taman Nasional Baluran Jawa Timur, Prosiding Seminar Nasional Biotik, 2015, pp. 201-213. [In Bahasa Indonesia]

[26] Balai Taman Nasional Baluran, Rencana Karya Lima Tahun (RKL) Balai Taman Nasional Baluran Periode Tahun 2003-2007, Direktorat Jenderal Perlindungan Hutan dan Konservasi Alam Balai Taman Nasional Baluran, Departemen Kehutanan. 2002. [In Bahasa Indonesia]

[27] E. Caesariantika, K. Toshiaki, N. Nobukazu, Impact of Acacia nilotica (L.) Willd ex Del Invasion on Plant Species Diversity in the Bekol Savanna, Baluran National Park, East Java, Indonesia Tropics 20(2) (2011). DOI: https://doi.org/10.3759/tropics.20.45.

[28] M. Baudena, S.C. Dekker, P.M. van Bodegon, B. Cuseta, S.I. Higgins, V. Lehsten, C.H. Reick, M. Rietkerk, S. Scheiter, Z. Yin, M.A. Zavala, V. Brovkin. Forest, Savannas, and Grasslands: Bridging the Knowledge Gap Between Ecology and Dynamic Global Vegetation Models, Biogeosciences. 12 (2015) 1833-1848. DOI: https://doi.org/ 10.5194/bg-12-1833-2015.
[29] M.T. Smith, Goodman PS. Successional Dynamics in an Acacia nilotica-Euclea divinorum Savannah in Southern Africa, Journal of Ecology 75(3) (1987) 603-610. DOI: https://doi.org/ 10.2307/ 2260192.

[30] Plants for A Future, Corypha utan - Lam, 2018. Available from: ttps://pfaf.org/user/Plant.aspx? LatinNa me=Corypha+utan.

[31] NFTA, Acacia leucophloea - shade and fodder for livestock in arid environments, NFTA 96-04, Waimanalo, 1996.

[32] A.C. Hendrik, C. Kusmana, Muhdin, Stand and Site Characteristic of Kabesak (Acacia leucophloea) in Timor Island, East Nusa Tenggara, Indonesia, Jurnal Penelitian Kehutanan Wallacea, 8(2) (2019) 147-157. DOI: http://dx.doi.org/ 10.18330/jwallacea.2019.vol8iss2pp147-157.

[33] Balai Taman Nasional Baluran, Taman Nasional Baluran: Secuil Afrika di Jawa (Sekilas Potensi Wisata Taman Nasional Baluran), Taman Nasional Baluran, Banyuwangi, 2007.

[34] C. Orwa, A. Mutua, R. Kindt, R. Jamnadass, A. Simons, Azadirachta indica, Agroforestry Database: A Tree Reference and Selection Guide Version 4.0, World Agroforestry Centre, Kenya, 2009.

[35] C. Orwa, A. Mutua, R. Kindt, R. Jamnadass, A. Simons, Ziziphus nummularia, Agroforestry Database: A Tree Reference and Selection Guide Version 4.0, World Agroforestry Centre, Kenya, 2009.

[36] I. Sazima, Cleaner Birds: a worldwide overview, Revista Brasileira de Ornitologia 19(1) (2011) 32-47. 